HOW CAN BLOGGING SUPPORT CRITICAL REFLECTIVITY IN FOREIGN LANGUAGE TEACHER EDUCATION? ${ }^{1}$

\title{
YABANCI DİL ÖĞRETMEN EĞITIMMINDE BLOGLAR ELEŞTİREL YANSITICI DÜŞÜNCEYİ NASIL DESTEKLER?
}

\author{
Sibel KORKMAZGİL ${ }^{2}$
}

\begin{abstract}
Başvuru Tarihi: 27-01-2018 Yayına Kabul Tarihi: 17
Abstract: This study was based on a belief grounded in the literature that more authentic reflective approaches should be implemented in order to encourage teachers to engage in many-way conversations with and within themselves, and that blogs as a transformational technology for teaching and learning can facilitate critical thinking and knowledge construction through interaction and collaboration with others with a shared interest. Thus, this 12-week-long case study seeks to examine whether the use of blogs as support for reflective practice in a Practicum course could enhance the level of critical reflection that the pre-service English language teachers were involved in. Data collection consisted of archival records of pre-service teachers' reflective blog posts and comments, pre- and post-study interviews with pre-service teachers and field notes taken by the researcher. The results of this study indicate that blogging supports the pre-service teachers' reflectivity positively. All of the preservice teachers are found to be reflective to a certain extent in their blog postings. However, there are differences in the degree of reflection they are engaged in. These results reveal specific evidence that contribute to our understanding of how blogging might be incorporated as to support for reflective practice in teacher education programs.
\end{abstract}

Keywords: Blog, foreign language teacher education, reflection, professional development, preservice teacher
Özet: Bu çalışma, öğretmenleri kendi aralarında çok yönlü iletişim içerisinde olmaya teşvik etmek için daha otantik yansıtıcı yaklaşımların uygulanması gerektiği, ve blogların, bu bağlamda, ortak ilgi alanlarını paylaşan kişilerle işbirliği ve etkileşim yoluyla bilginin inşasına ve eleştirel düşüncenin gelişimine olanak sağlayacak bir dönüştürücü eğitim öğretim tekbolojisi olduğu inancı üzerine kurulmuştur. $\mathrm{Bu}$ nedenle, 12 haftalık bu örnek olay çalışması, Öğretmenlik Uygulaması dersinde yansitıcı uygulama desteği olarak kullanılan blogların, İngilizce öğretmen adaylarının eleştirel yansıtıcı düşünme düzeyini artırıp artırmayacağını incelemeyi amaçlamaktadır. Öğretmen adaylarının yansıtıcı blog yazıları ve yorumlardan oluşan arşivsel kayıtları, çalışma-öncesi ve sonrası yapılan görüşmeler ve araştırmacı tarafindan çalışma süresince tutulan gözlem notları bu çalışmanın veri toplama yöntemlerini oluşturmaktadır. Bu çalışmanın sonuçları blogların öğretmen adaylarının yansıtıcı düşünmelerini olumlu bir şekilde desteklediğini göstermektedir. Tüm öğretmen adayları blog yazılarında belirli bir seviyeye kadar yansitıcı bulunmuşlardır. Ancak, yansitıcı düşünme derecelerinde bireysel farklar da mevcuttur. $\mathrm{Bu}$ sonuçlar, blog yazarlığının öğretmen eğitimi programlarında yansitıcı uygulamayı desteklemek için nasıl kullanılabileceği konusundaki anlayışımıza katkıda bulunan sonuçları ortaya koymaktadır.

Anahtar Sözcükler: Blog, yabancı dil ögretmen eğitimi, yansitıcı düşünce, mesleki gelişim, ögretmen adayl

\section{Introduction}

Reflection has been one of the concepts widely examined and discussed in the teacher education. Reflective thinking involves the process of linking theory and practice to make informed decisions

\footnotetext{
${ }^{1}$ This article is based on the unpublished M.A. thesis entitled as How does Blogging Enhance Pre-service English Language Teachers' Reflectivity in Practicum which was submitted to Middle East Teachnical University in 2009.

${ }^{2}$ Dr. Öğr. Üyesi Sibel KORKMAZGİL, Cumhuriyet Üniversitesi, Eğitim Fakültesi, Yabanci Diller Eğitimi Bölümü, sibelkorkmazgil@gmail.com, ORCID No: 0000-0002-6573-3390
} 
regarding educational issues, and then assessing the possible consequences of these decisions which may cause a change in behavior (Taggart \& Wilson, 2005). Teachers need to engage in continued knowledge development which will guide their actions in their practice. Thus, self-inquiry and professional development are important components of reflective practice, and teacher education programs seek to find ways to promote reflective thinking among pre-service teachers. The benefits of reflective practice have spurred teacher educators to develop reflective activities for pre-service teachers. Gelter (2003) argues that reflection is not a spontaneous activity, and reflective capacity has to be learnt. Of varying reflective approaches and techniques, journal writing, often cited with positive outcomes, is the most widely used technique in studies into reflective practice. However, Stiler and Philleo (2003) note that with the traditional journal format "the outcomes were considered to be inadequate. Students wrote sparse, descriptive summaries with few examples of heightened levels of awareness and little indication that these practices promoted a continuing routine of reflective practice" (p. 789). Of the other problems related to hard-copy journals or diaries are "the legibility of handwritten documents, instructor response time, record-keeping concerns, and the transportation of ...written student journals" (ibid., p. 789).

Despite the widespread emphasis on reflection, research into the reflective practice yield disappointing results. Studies show the pre-service teachers have difficulty achieving higher levels of reflection (Hatton \& Smith, 1994; Galvez-Martin, Bowman \& Morrison, 1998; Liou, 2001) or reflecting on wider contexts of teaching and learning other than immediate concerns of instruction such as classroom management and control (McLaughlin \& Hanifin, 1994). Furthermore, Gelter (2003) states that reflective thinking is uncommon among the practitioners in education. Although reflective tasks have mostly been assigned in the university education, reflective practice cannot turn into a professional skill or behavior. Furthermore, there is little research evidence to show whether the strategies used are effective or not. "Merely providing preservice teachers with opportunities to reflect and activities that encourage reflection does not guarantee that reflection will occur" (Mewborn, 1999, p. 317). However, few teacher educators and researchers can disagree with the idea that teachers should be encouraged to engage in some kind of reflection in order to develop into better professionals. Then, the question needs to be answered is "how". How can we make the practitioners more reflective? How can we ensure that reflective thinking will occur when teachers are struggling with their workload in their busy lives?

\section{Blogs as a Reflective Device}

Teacher educators should explore multiple opportunities (Bean \& Stevens, 2002) and more authentic reflective tools to enhance reflectivity among pre-service teachers. With the advance of information and communication technology (ICT), new opportunities have been created in terms of learning, teaching and assessment. The growth of interest in the use of Internet for educational purposes makes teaching and learning go beyond the boundaries of classrooms and let people all around the world be only one-click away from each other. The knowledge is generated not individually, but collectively. This ever-growing flow of information, and interactive and more authentic communication tools have made significant implications for education. Thus, the integration of educational technology in teacher education programs can support the teaching of reflective capacity (Shoffner, 2006). One of these emerging technological tools for reflection is the technology of weblogs which is mostly regarded as a new genre of web-publishing tool or an online 
journal. Being one of the second generation Internet tools (Web 2.0), blogs can make it possible for people not only to share their ideas with the rest of the world, but also to get feedback from others.

One of the characteristics that make educational tools successful is whether they have a low threshold and a high ceiling (Myers, Hudson \& Pausch, 2000). The threshold refers to how difficult it is to learn how to use a system and the ceiling refers to how much can be done using that system. Therefore, an ideal educational technology should be relatively easy to comprehend and use, and at the same time should provide wide ranging application to its users. Blogs, mostly regarded as a new genre of web-publishing tool or an online journal, have a wide range of application; from personal online journals or diaries to their use for journalism, politics, knowledge sharing, or as news filters. In education, blogs can also be used for varying purposes, such as providing communication channels among teachers and students or resource center (Oravec, 2002), self-publishing (Kajder \& Bull, 2003; Stiler \& Philleo, 2003), supporting in-class discussion and interaction (Wang \& Hsua, 2008; Wassell \& Crouch, 2008) or as learning spaces in a higher education context (Martindale \& Wiley, 2005; Williams \& Jacobs, 2004). Both this wide ray of blog application in education and the fact that anyone can create his or her blog in a few minutes using the free blog hosting services on the Net ensure that this technology has a low threshold and a high ceiling. This is one of the reasons why blogs were chosen as the instrument for the current study.

The instructional benefits of blog use to enhance learning have been noted by many studies (Bartlett-Bragg, 2003; Brescia \& Miller, 2006; Martindale \& Wiley, 2005) mainly based on the assumption that blogs can facilitate critical thinking and knowledge construction (Kajder \& Bull, 2003; Oravec, 2002). In order to formulate their response to others on the Web students are required to consider different viewpoints in the light of their conceptions, and then defend their own opinions. Oravec (2002), therefore, clearly points out that "the weblog has many dimensions that make it well suited to students' unique voices" (p. 618), empowering them, and thus, encouraging them to become more critical and analytical in their thinking. Since blogs provide students both with a high level of autonomy and opportunities for interaction with peers, they have the potential to be a transformational technology for teaching and learning (Williams \& Jacobs, 2004). Thus, the use of this transformational technology may be well suited to the aims of teaching reflective capacity to pre-service teachers. Shoffner (2005) argues that "weblogs offer an alternative to the traditional journal format, while retaining many of the more positive aspects" (p. 2096). The electronic availability; archiving the entries; the public nature of weblogs allowing readers to leave comments; including hyperlinks to outer resources via the Web; the sense of ownership, and the opportunity of having a personal space to deliberate thoughts and ideas are only some of the benefits of blogging experience which help pre-service teachers broaden the discussion and learning outside the classroom (Kennedy, 2003; Shoffner, 2005; Shoffner, 2006). Additionally, some other studies have suggested that blogs may promote reflective practice among practitioners (Ray \& Hocutt, 2006; Shoffner, 2005; Suzuki, 2004; West, Wright, and Graham, 2005).

In this study blogs are explored as a reflective tool to enhance the reflective practice among preservice teachers. It is believed that weblogs can provide a non-threatening but moderately challenging environment where pre-service teachers can reflect on their ideas and feelings, and generate knowledge in collaboration with the multiple perspectives. Thus, this case study aims to investigate how the integration of blogging in a practicum course promotes reflective practice 
among pre-service English language teachers. The secondary purpose of this study is to introduce to these pre-service teachers the pedagogical and learning benefits derived from the integration of such social sharing technologies. The research questions that guide this study are as follows:

1. What do the pre-service teachers write about in their blogs?

2. What is the level of reflection demonstrated in the blog posts which are distributed based on the categories of topics derived out of the study? Is it descriptive or critical?

3. What is the difference between blog posts and comments in terms of the level of reflectivity?

4. How does the reflectivity change over time through blogging?

\section{Methodology}

\section{Participants}

12 pre-service English language teachers (9 females and 3 males) - a section of the Practice Teaching course in the Department of Foreign Language Education at Middle East Technical University (METU) - participated in this semester-long case study. Other participants were the commentators to the blogs, who were defined as the "anonymous contributors" in the study.

\section{The Course}

Pre-service teachers who take Practice Teaching at the last semester of their undergraduate education are both required to conduct field visits in pre-assigned schools and to attend on-campus seminars. In the school observations they are expected to follow and fill in structured observation tasks given by the course instructor. They are also required to do a microteaching in the assigned school classrooms they observe. Furthermore, on-campus seminars, they discuss different instructional issues such as classroom management, classroom interaction and integrating skills. Thus, the course mainly aims to develop their professional knowledge and practice in language teaching by providing student teachers with opportunities to challenge their views and thoughts, and evaluate the nature and processes of foreign language teaching through direct and indirect experiences. Therefore, the nature of this course is likely to be well-suited to the purpose of the current study focusing on the development of the reflective skills through blogging. As part of the Practicum Course, the participants in this study were all attending to a private school in Ankara.

\section{Research Design}

Participants' blogs. The blogging activity was not a compulsory component of the course meaning that the participants would not be graded either for their participation or for their endproducts. This allowed them to have the ownership of their blogs, and the responsibility to initiate the activity and discussion on their blogs (Shoffner 2006; Shoffner, 2008; Yurkiw 2006). Blogger was chosen as the blog-hosting service because it was popular, free and user-friendly. Some decisions were made prior to the study: participants could publish posts only on their own blogs, and the blogs would be open to public on the Internet - inviting readers to leave comments on their blog postings. 
Class blog. The researcher set up a class blog named Reflective Practicum where pre-service teachers' blogs were displayed as links. This blog acted as the central blog for online communication. Facilitative activities were posted on this blog and participants in the study were invited to post entries on their own blogs or to publish comments on the class blog. Furthermore, this blog was used for other purposes such as informing pre-service English language teachers of the relevant conference events, useful resources and recent news in education.

Facilitative activities. In order to familiarize the partcipants with blogging and initiate discussion on the blogs, three facilitative activities were conducted throughout the study. Furthermore, participants were encouraged to blog not only about the issues of teaching and learning, but also about their social and private lives. Face-to-face meetings were held with the participants on regular basis in order to provide information about the research study and technical assistance on blog use. Since all the participants blogged about their reflective practices, they shared a common topic and this common passion or topic led to the formation of what White (2006) called a topic centric community. In this type of blog communities "both power and identity is distributed across the community.... The rich network of perspectives allows the readers many views on an issue" (White, 2006, p. 4). Furthermore, this study employed some other technologies White (2006) considered as supportive to the formation of topic centric communities. First of all, all the participants linked to other participants' blogs via blogroll. The blogroll used in their blogs allowed for access not only to the blogs themselves, but also to the updated content via RSS. Furthermore, the participants attached a shared tag, begin2blog, to all of their blog posts, which could mark their posts as relevant to a community (White, 2006). Additionally, a yahoo email list among the participants was maintained to keep information organized or communicate informally.

\section{Data Collection Procedures}

Qualitative research methods were employed in order to obtain rich and detailed data embedded in context. Numerous data sources such as archival records of pre-service teachers' reflective blog posts and comments; pre- and post-study interviews with pre-service teachers and field notes taken during the study were used to collect and triangulate the data. Pre-study interviews were conducted in order to have general information about their use of Internet, their familiarity with such technologies and their views on integrating technology in language teaching and learning. Poststudy interview protocol was administered in order to learn about their blogging experience, the challenges and complaints with using blogs and their views about integrating such technologies in their future teaching. The instructor kept an observation log during the semester as well. She took notes and reflections about how the participants experienced this blogging phenomenon and what problems or challenges occurred while using their blogs. The researcher observed the activities not only in the participants' blogs, but also in the yahoo email group that she created in the study. Observing the email exchanges among the participants provided information about what challenges they experienced when they blogged. It was planned that the logs the researcher kept would be used when the data were analyzed and interpreted.

\section{Data Analysis}

The current study utilized a modified version of Ho and Richards' (1993) categories as a priori framework for data analysis in order to be able to determine the recurring patterns occurred in pre- 
service English language teachers' blog postings. All the blog content was archived and available on the Internet throughout the study. The data were coded according to the topics that the participants wrote about in their blog postings, and these topics served as a measure of critical reflectivity. Earlier and later blog postings were compared to check evidence of change in the level of the pre-service teachers' reflective thinking. In order to ensure reliability, a second rater analyzed and coded $20 \%$ of each participant's randomly selected blog postings. It was observed that almost $90 \%$ of the codes assigned by two coders matched. The coders reached a consensus about the parts of the data they had coded differently.

\section{Results}

\section{Blog Use Statistics}

The descriptive statistics of the blog posts and comments published throughout the study provides an insight into how much blogs are used in the study. Table 1 illustrates the distribution of the posts per week published by the participants while Table 2 shows the distribution of the comments per week left by both the participants and the anonymous contributors on the Web throughout the study. Over the duration of 12 weeks, there were 119 total posts published on the blogs and 367 total comments associated with those posts. There was a mean of 9.92 posts/week, a mean of 30.58 comments/week, and a mean of 3.08 comments/post. 119 blog posts were published by 12 preservice teachers, who participated in the study since it was planned that readers were not allowed to publish posts in the participants' blogs. Of the 367 total comments, 262 were posted by the participants and 105 were posted by anonymous contributors on the Web, including the researcher and the instructor of the course. These 105 comments were left to the participants' blog posts by 29 different people. As for the participants' engagement, the results revealed that each participant published an average of 9.92 blog posts and 21.83 comments during the12-week time span.

Table 1

Posts by Week

\begin{tabular}{lllllllllllll}
\hline Weeks & 1 & 2 & 3 & 4 & 5 & 6 & 7 & 8 & 9 & 10 & 11 & 12 \\
\hline Participants' Posts & 21 & 15 & 5 & 6 & 3 & 9 & 10 & 18 & 6 & 10 & 9 & 7 \\
\hline
\end{tabular}

Table 2

Comments by Week

\begin{tabular}{lcccccccccccc}
\hline $\begin{array}{l}\text { Weeks } \\
\text { Comments }\end{array}$ & 1 & 2 & 3 & 4 & 5 & 6 & 7 & 8 & 9 & 10 & 11 & 12 \\
\hline Participants & 12 & 39 & 4 & 21 & 10 & 27 & 32 & 33 & 16 & 25 & 20 & 23 \\
Anonymous contributors & 6 & 4 & 5 & - & - & 6 & 11 & 38 & 20 & 6 & 1 & 8 \\
Total & 18 & 43 & 9 & 21 & 10 & 33 & 43 & 71 & 36 & 31 & 21 & 31 \\
\hline
\end{tabular}

\section{What do the pre-service teachers write about?}

The recurring patterns in the blog postings were grouped under the categories of topics, and these topics with relevant frequencies are presented in Table 3. The most frequent topics were related to 
the participants' disclosing their personal details. On the other hand, the distribution of topics through Category 1 to 5 is of great importance to the interpretation of the findings of the study since they contain topics related to teaching and learning issues. Of these categories, the most frequent topics belong to the theories of teaching, followed by descriptions of the approaches and methods the participants observed in the assigned school in the Practicum course, evaluation of teaching, self-awareness of their strengths and weaknesses as a prospective teacher. Of the questions formulated by the pre-service teachers in their blog postings, the majority of them contain questions asking for advice and suggestions.

Table 3

Topics in blog postings

\begin{tabular}{|c|c|c|c|c|}
\hline \multirow{2}{*}{$\begin{array}{l}\text { Topic } \\
\text { Category }\end{array}$} & \multirow[t]{2}{*}{ Sub-category } & \multicolumn{3}{|c|}{ Frequency } \\
\hline & & Total & $\begin{array}{l}\text { Category } \\
\text { total }\end{array}$ & $\begin{array}{l}\text { Average } \\
\text { (Mean) }\end{array}$ \\
\hline \multirow[t]{3}{*}{ Theories of teaching } & Theory & 219 & \multirow{3}{*}{223} & 18.25 \\
\hline & Application & 4 & & 0.33 \\
\hline & Approaches \& Methods & 40 & & 3.33 \\
\hline \multirow{4}{*}{$\begin{array}{l}\text { Approaches \& } \\
\text { Methods }\end{array}$} & Content & 14 & \multirow{4}{*}{166} & 1.17 \\
\hline & Teacher's knowledge & 26 & & 2.17 \\
\hline & The learners & 40 & & 3.33 \\
\hline & School Context & 46 & & 3.83 \\
\hline \multirow{3}{*}{$\begin{array}{l}\text { Evaluating } \\
\text { teaching }\end{array}$} & Evaluating & 65 & \multirow{3}{*}{143} & 5.42 \\
\hline & Problems & 48 & & 4.00 \\
\hline & Solutions & 30 & & 2.50 \\
\hline \multirow[t]{3}{*}{ Self-awareness } & $\begin{array}{l}\text { Perception of self as a } \\
\text { teacher }\end{array}$ & 20 & \multirow{3}{*}{133} & 1.67 \\
\hline & $\begin{array}{l}\text { Recognition of } \\
\text { personal growth }\end{array}$ & 31 & & 2.58 \\
\hline & Setting personal goals & 82 & & 6.83 \\
\hline \multirow{3}{*}{$\begin{array}{l}\text { Qs about } \\
\text { teaching }\end{array}$} & Asking for reasons & 6 & \multirow[b]{2}{*}{75} & 0.50 \\
\hline & $\begin{array}{l}\text { Asking for advice \& } \\
\text { suggestions }\end{array}$ & 69 & & 5.75 \\
\hline & Sharing personal info. & 143 & \multirow{3}{*}{351} & 11.92 \\
\hline \multirow{2}{*}{$\begin{array}{l}\text { Disclosure of the } \\
\text { personal interests }\end{array}$} & Informal Support & 136 & & 11.33 \\
\hline & Career plans & 72 & & 6.00 \\
\hline
\end{tabular}

\section{What is the level of reflection demonstrated in the blog posts?}

The following conclusions can be drawnregarding the extent of critical reflection in each category:

Theories of teaching. Participants were found to reflect critically on their personal theories of teaching rather than reflection on how the theories were applied in their lessons.

Approaches and Methods. The critical traits of reflection in this category centered on the evaluation of school context and the characteristics of learners that may affect the design and implementation of teaching process. Participants were also engaged in teachers' experience and 
knowledge about both the demands of the class task and classroom management. For example, teaching grammar either implicitly or explicitly was one of the hot topics about which the participants shared their own personal opinions. They seemed to have conflicting ideas related to grammar teaching. For example, one of the participants described this in her blog post as follows:

Our mentor teacher teaches the grammar topics in a very effective way that I really appreciate her. I always thought that teaching grammar inductively would be too difficult although I am sure that it would be effective. However, our mentor teacher manages it perfectly; she teaches inductively in a very simple and natural way and I begin to think that I can manage it, as well. She simply creates an environment where the students can only use that structure and she gives chance to every student to speak. Now I do not think that teaching grammar inductively would be that difficult. (Participant5's Blog).

This post received 9 comments from the participants and the anonymous contributors. For example, two participants (Participant1 and Participant9), stated that they were of the same opinion with the Participant5. Although they believed that it was the most effective way to do, they found teaching grammar inductively a little bit challenging. On the other hand, the comments by the anonymous contributors comprised explanations that are more detailed. For example, addressing to Participant5, Carla, a Brazilian English teacher from Florida talked about her experiences in her comment that:

I guess there's no formula. I generally teach grammar very inductively, but the most important aspect of it is to make it relevant to students, letting them use language in a meaningful and contextualized way. Sometimes, just by giving a simple plain grammar explanation might help instead of battling to show a concept to students. However, in general, I truly believe in the power of letting students realize what we are talking about with the teacher's guidance. What do you think? (Carla's Comment)

Participant5 approached the topic in a similar way. There appeared an exchange of ideas between Carla and Participant5 on the issue, followed by again Carla's comment confirming what Participant5 had said before. Participants kept discussing this topic in other blog posts and comments. Participant9, for example, elaborated the topic through the descriptions of how particular grammatical subjects could be taught. She posted 5 successive posts elaborating her opinions about teaching grammar. It was possible to see the gradual progress in her reflections. In her first two posts, she described some of the techniques that her mentor teacher applied in vocabulary teaching. Having described a follow-up activity for vocabulary teaching in which students were required to create a story in groups by accomplishing individual parts on their own, Participant9 reflected upon the possible advantages of that activity:

At the end of the activity, there was a full story that the students themselves created using the target vocabulary items. As you see our mentor teacher gives her students some "autonomy" in their learning. Or you may call this "responsibility", too. The students have the responsibility for their learning. They realize that when they do not participate in the activity, there will be no learning on the part of them. Thus, the teacher also aims to keep the students' attention on the activity and creating their own products. Another advantage of this activity is that the teacher helps the students internalize the newly- learnt items in a meaningful task. So my dear friends, it is all about the activity. What do you think? Does it make sense to you? Can it work in your class? Do you want to add some more aspects to it if it is not efficient in your own opinion? (Participant9's blog post). 
This post initiated a substantial amount of discussion. For example, an EFL teacher educator from Israel, Randi suggested other activities in his comment:

I really enjoyed your blog posting. When kids create their own stories, even the weakest learner can read at least his or her own sentence! This is a great way to have kids meet with success. Here are some suggestions to build on this activity. Why not write the story on tagboard or on a large flipchart if one is available? Then you can begin a collection of stories. As the school year progresses, learners realize how much English they've learned! Another suggestion is to copy the story and either photocopy it for everyone, or put it online. You can use it for anything from reading comprehension to looking for aspects of phonics (e.g., have kids circle all of the words with a silent 'e') to drawing comic strips of the story.It sounds like you're having a wonderful experience! I'd love to hear more. From an EFL teacher educator and consultant in neighboring Israel! (Randi's comment)

Having reflected upon the techniques of her mentor teacher, Participant9 suggested other activities indicating her approaches in three blog posts entitled A Roadmap for Teachers, Conducting an Explicit Teaching, Reading Skill with a Grammar Point. When she was asked about the motives underlying these posts in the post-study interview, it was understood that getting comments from educationalists from different parts of the world and even forming some kind of a shared bond between these people urged her to feel confident about her opinions, and reformulate and further express her own ideas on her blog. In addition to Participant5 and Participant9, other participants such as Participant1, Participant2 and Participant10 also discussed grammar teaching on their blog postings. Each of the participants approached the issue from different angles. While Participant10 focused on relating her opinions about communicative language teaching, Participant2, for example, compared the current methodological views with those of the time she began to learn English when she was a little child by taking into account the wider, social and political perspectives. This discussion around grammar teaching clearly showed how the participants leveraged their blogs.

Evaluating Teaching. The participants seemed to reflect more critically on evaluating the lessons they observed, and their assessed teaching experiences either positively or negatively. Most of the participants shared their opinions before and after their assessed teaching. Some of them asked for suggestions and advice while they were designing the lesson plan, some blogged about the feedback they received from their mentor teacher and classmates who observed their assessed teaching, or some suggested some tips for others a well-prepared assessed teaching while analyzing theirs. Furthermore, participants were found to be more problem-oriented than reflecting upon solutions. The problems primarily focused on classroom management.

Self-awareness. Critical traits of reflection in this category were mostly gathered around setting personal goals. Every participant in the study reflected on the aspects of their teaching that needed improving in the future. Congruent with the fact that they were pre-service teachers, they had had very little teaching practice in a real setting so far. Thus, it was found that they reflected less on their perception of themselves as a teacher. This interactive and friendly atmosphere encouraged them to share their very sincere feelings on their blogs. Participant8, for example, in one of her blog posts entitled I am confused $\odot$ stated that she was not sure about being a teacher any more. She asked help and understanding by saying: 
I want to state one of my problems about being a teacher *: Our mentor teacher tries to be beneficial for us as possible as she can be. On Wednesday, she gave us some assignments of the students in order to check them. She explained how we should check them; what the criteria we should consider into, which symbols we should use to show the wrong things, etc. All these are fine... While checking the assignments in the evening, I feel like a real teacher who studied at her home also. This is my problem $*$ I feel the burden on the teachers that their work does not finish in the school, but goes on at their home and in their free times. So I feel a bit depressed and already bored with my future occupation. I really wonder whether you have this kind of negative feelings about being a teacher or not.. Am I the only one who depressed about her future job at the very beginning of it?!! (Participant8's Blog)

Participant 8 received 12 comments to this post; 5 comments by the other participants in the study, 7 by the anonymous contributors. Almost all of the comments included understanding and encouraging messages. Furthermore, the pre-service commentators approached the issue by reflecting the reason why they really wanted to be a teacher. Participant8's post seemed to make them think about how they could handle with the workload in the future. The anonymous contributors, identified themselves as teachers, approached this issue more cautiously since they knew what was awaiting these prospective teachers. One of the anonymous contibutors, an English teacher in France, suggested an online conference and some tips for dealing with the hard workload and burnout in her comment. Another anonymous contributor left a comment as follows:

Great question! I think teaching is really about being passionate about it and its possibilities and how you can impact in very subtle ways your students' lives. No, the work is not reduced ever! In fact, as years pass by, you can even spend more hours related to your profession because it's not just your classroom, you always need to look for professional development and getting better in what you do. Maybe teaching is for you, maybe not. You need to see if that's what you really want to be doing for the rest of your life or if there's something else that drives you, that really makes you happy and willing to do your best. What do you see yourself doing in 10 years that would make you happy? Cheers from a passionate Brazilian educator in Key West, FL. (Participant8's Blog)

The other comments that Participant8 received relevant to her post seemed to make her reconsider her feelings and thoughts about the issue since she published a comment in response to the comments indicating that she changed her mind:

thank you all for your precious comments:)) now I am not desperate about my future job beacuse of its workload, on the contrary I feel ready to work hard and to do my best in my future career as a teacher. I can work everywhere even after my work finishes at the school because I am too young and full of energy to work in my dreamy job "a teacher foreign language" :) (Participant8's Blog).

Questions about teaching. The participants formulated very few reflective questions in their blog postings throughout the study compared to the other types of questions asking for advice and suggestions. Instead of asking for reasons, they preferred to speculate and discuss possible reasons underlying some deeper issues in their blog postings. Thus, it was possible to say that blogs provided the participants much room for self-expression. Although participants engaged in different levels of critical reflection, what was common to almost all of the participants' blog postings was that the topics introduced in the blog postings were frequently discussed in the comments left by the 
readers of that post from different reflective viewpoints, which initiated the emergence of new topics as well as discussions. Thus, the difference between blog posts and comments published on the participants' blogs during the study needs to be explored.

\section{What is the difference between blog posts and comments in terms of the level of reflectivity?}

Considering the opportunities of interaction and communication that the blog posts and comments provided in the study, it was possible to state that they had different features in nature. Therefore, it is important to explore the level of reflection the participants are involved in each situation. Table 4 illustrates the extent of reflectivity the participants are engaged in the blog posts and comments. The most frequent traits of reflectivity belong to the personal theories of teaching (25\%), followed by reflections about the evaluation of teaching (26\%), approaches and methods the participants reflected upon (25\%), and self-awareness (18\%). Only 4 reflective questions $(1.5 \%)$ are formulated in the blog posts during the study.

Taking the distribution of the frequencies of the traits of critical reflectivity in the comments according to the initial five general categories, the most critical category is found to be again the personal theories of teaching (39\%). However, there are differences as to the ranking of the other categories in terms of the level of reflectivity compared to the results discussed above. The reflections on the personal theories of teaching are followed by descriptions of the self-awareness topics $(25 \%)$, evaluating teaching $(22 \%)$ and approaches and methods $(13 \%)$. In the comments the participants left to the blogs, there are very few reflective questions $(0.6 \%)$.

Table 4

The extent of reflectivity in blog posts \& comments

\begin{tabular}{llcccc}
\hline \multirow{2}{*}{ Topic Category } & \multicolumn{2}{c}{ POSTS / Frequency } & \multicolumn{2}{c}{ COMMENTS / Frequency } \\
& Total & Mean & Total & Mean \\
\hline 1. Theories of teaching & 76 & 6.33 & 126 & 10.50 \\
2. Approaches \& Methods & 69 & 5.75 & 43 & 3.58 \\
3. Evaluating Teaching & 72 & 6.00 & 71 & 5.92 \\
4. Self awareness & 50 & 4.17 & 83 & 6.92 \\
5. Questions about Teaching & 4 & 0.33 & 2 & 0.17 \\
\hline
\end{tabular}

Looking globally at these tables, the following conclusions can be drawn:

- Participants reflected most critically on their personal theories of teaching both in their posts and comments.

- They were more reflective in their comments than they were in their blog postings.

- The participants were more problem oriented in their posts. They reflected on the rationale behind lessons, and discussed reasons that gave rise to specific problems. However, the range of solutions possible was pointed out in the comments relevant to these posts.

- Participants were seen to be more engaged in reflecting on their self-awareness of their strengths and weaknesses as prospective teachers in their comments. While interacting with the others through comments, they evaluated some aspects of their teaching that needed to be developed in the future and more frequently commented on their professional goals. 


\section{How does the reflectivity change over time through blogging?}

The findings related to the development of the pre-service teachers' reflectivity over time are illustrated in the Table 5. Overall it seems that almost all of the participants began to display their personal theories of teaching. Moreover, they were more able to discuss problems and offer their own solutions. Then, they became better problem solvers. However, they did not ask more reflective questions. The overall impression derived from the analysis was that the pre-service teachers changed their focus of critical reflection in varying degrees throughout the study. When the reflectivity of these participants was analyzed, it was found that their level of reflectivity developed significantly in almost all of the seven traits over time. Some pre-service teachers' later blog postings showed a slight increase in the kinds of critical reflectivity they employed. Since no clear patterns of development or change was observed, the results relevant to those traits remained either unclear or mixed. It is important to note that identifying some traits as showing no signs of development in critical reflection did not mean that these participants did not show any evidence of critical reflection in that specific trait. On the contrary, all of them were found to reflect critically in all of these aspects in varying degrees. However, they did so when they began blogging, and keep reflecting in the same way throughout the study.

Table 5

The development in the level of critical reflections as shown in the blog postings (Adapted from Ho and Richards, 1993)

\begin{tabular}{|c|c|c|c|c|c|c|c|c|c|c|c|c|}
\hline \multirow{2}{*}{$\begin{array}{l}\text { Traits of development in } \\
\text { critical reflection }\end{array}$} & \multicolumn{12}{|c|}{ The development in the degree of critical reflection } \\
\hline & $\mathrm{P} 1$ & $\mathrm{P} 2$ & P3 & P4 & P5 & P6 & P7 & P8 & P9 & P10 & $\mathrm{P} 11$ & $\mathrm{P} 12$ \\
\hline $\begin{array}{l}\text { Engaging in a greater variety } \\
\text { of types of reflectivity over } \\
\text { time }\end{array}$ & + & + & - & + & + & - & - & - & + & + & $+1-$ & - \\
\hline $\begin{array}{l}\text { Being more able to discuss } \\
\text { their personal theories of } \\
\text { teaching }\end{array}$ & + & + & + & + & + & + & + & + & + & + & + & $+/-$ \\
\hline $\begin{array}{l}\text { Being more able to reflect } \\
\text { through experiences of } \\
\text { teaching }\end{array}$ & + & + & - & + & + & - & - & - & + & + & - & - \\
\hline $\begin{array}{l}\text { Being able to go beyond the } \\
\text { classroom to the broader } \\
\text { context }\end{array}$ & + & + & $\begin{array}{l}+1 \\
-\end{array}$ & - & + & $\begin{array}{l}+1 \\
-\end{array}$ & - & + & + & + & - & - \\
\hline $\begin{array}{l}\text { Being more able to evaluate } \\
\text { both positively and negatively }\end{array}$ & + & - & - & $\begin{array}{l}+1 \\
-\end{array}$ & + & - & + & - & + & + & - & - \\
\hline $\begin{array}{l}\text { Being more able to discuss } \\
\text { problems and come up with } \\
\text { their own solutions }\end{array}$ & + & + & - & + & + & - & - & + & $+1-$ & + & $+1-$ & - \\
\hline $\begin{array}{l}\text { Being more able to ask more } \\
\text { questions about teaching }\end{array}$ & + & - & - & + & - & - & - & - & + & - & - & - \\
\hline $\begin{array}{l}\mathrm{P}, \text { represents participant; } \\
+ \text { indicates signs of development }\end{array}$ & & & 5 & & & (1) & & & +1 & 4 & Inclea & \\
\hline
\end{tabular}




\section{Discussion}

The results indicate that blogging supports the pre-service teachers' reflectively positively. All of the pre-service teachers were reflective to a certain extent in their blog postings. However, there are differences in the degree of reflection that the participants engaged in. Participants with negative attitudes towards technology contribute to a lesser extent than the ones who wish to integrate such tools in their future teaching. Additionally, participants use blogs for other purposes such as disclosing personal details, their career plans and concerns, and announcing social events, news and educational conferences. This social sharing and interaction among the participants has empowered their sense of belonging to a community and their autonomy as learners. Pre-service English language teachers in the study frequently engaged in narrating their own approaches and views related to teaching a foreign language. Most of the discussion through blogs has centered on personal opinions. This is congruent with the findings of Herring, Scheidt, Wright and Bonus' (2005) study revealing that most of the blogs in their randomly selected corpus are found to be "individualistic, even intimate, forms of self-expression" (p. 163). Being a self-publishing tool, one of the most valued characteristic of blogging is its potential of providing the bloggers with the opportunity for self-expression and perhaps the "self-reflection that accompanies considerations" (Brescia \& Miller, 2006, p. 49).

Some interesting conclusions can be drawn when the related literature is examined. Farrell (1999), for example, indicated that the three experienced EFL teachers in his study were more interested in talking with their theories of teaching and the problems that they faced in teaching just like the results of this current study did. Furthermore, the pre-service teachers in Liou's (2001) study were more concerned about evaluating teaching of the teacher they were observing in the practice teaching course especially in terms of the classroom teaching approaches or methods he or she used. Comparing his results to Farrell's (1999), Liou (2001) discussed that the instrument he used - that is, the written reports - may have inhibited the student teachers' reflectivity. He suggested that providing a lower affective state may be helpful to trigger the development of reflectivity for teaching. What these two studies suggest is significant in the light of the findings of this study. First of all, compared to the traditional pen-and-paper journals or reports submitted only to the instructor, the blogs used as the instrument of this study provided a non-threatening but moderately challenging environment where pre-service teachers could reflect on their ideas and feelings, and generate knowledge in collaboration with the multiple perspectives. Moreover, they provided the pre-service teachers with unlimited number of audience to interact when compared to the fact that the three teachers in Farrell's study (1999) had only themselves to share their opinions. Therefore, it might be possible to say that practitioners are more likely to go beyond just stating their evaluation of what happens in a particular lesson to discuss their personal opinions and theories of teaching when they are given opportunities to interact and collaborate.

The pre-service English language teachers in the study were frequently problem-oriented in their blog postings. They described the problems they faced in the Practicum course on their blogs. The problems they emphasized on their blogs were mainly about classroom management techniques, and pedagogical difficulties that students had in understanding certain grammatical subjects. When the related literature is examined, it is seen that practitioners are mostly concerned with these issues (Liou, 2001; Farrell, 1999; Yang, 2005). Since they were going to graduate and take responsibility 
of teaching in their own hands very soon, it was apparent that they were afraid of the unexpected. Although they had acquired sufficient pedagogical or methodological knowledge, they had not had enough experience in teaching. When they got suggestions from professionals or other colleagues on the Internet, it seemed that they felt more relaxed and secure. The problems mentioned in blog posts were found to initiate a substantial amount of discussion and interaction. Furthermore, participants also engaged in different types of reflectivity when either they discussed the factors contributing to the problem, or possible solutions related to the problem. Therefore, the problems the participants mentioned in their blog posts facilitated reflection and critical thinking among the participants.

Pre-service English language teachers blogged about several topics relating to teaching and learning issues. However, it was interesting that no matter what they discussed in their blog postings, the discussion almost always came to a point where they reflected upon their views of what it was like to be a teacher. Their practicum experiences spurred them to identify aspects of their teaching to work and develop in the future. Congruent with the fact that they had had little teaching experience in a real setting so far, they reflected less on their perception of themselves as a teacher, but more on their professional goals. Therefore, most of the participants focused primarily on participants' goals as a prospective teacher.

Unlike pen-and-paper journal writing (Ho \& Richards, 1993; Farrell, 1999; Liou, 2001), blogging seems to facilitate critical thinking and increase self-awareness. But why is this so? This question needs careful consideration. The implications of the current study make it possible to trace the possible explanations to this question on two different domains; one is related to the communicative and collaborative characteristics of blogging, and the other is about the kinds of reflection the participants are involved in through their blogs.

First of all, one may well assert that the collaborative and interactive nature of blogging engender this kind of reflectivity among the pre-service teachers. "Weblogs offer an alternative to the traditional journal format, while retaining many of the more positive aspects" (Shoffner 2005, p. 2096). Studies which employed the pen-and-paper journal writing as a tool to facilitate reflection revealed some problems such as lack of ideas in journals (Lee, 2007) or difficulty in sustaining interest in writing journals (Ho \& Richards, 1993; Lee, 2007; Liou, 2001). When the instructor is the only reader of the students' journals, it is quite normal that students may consider journal writing as a way to communicate with the instructor or as a kind of assignment rather than a tool to facilitate reflection.

Why do we have to confine ourselves to interacting only with the people from the immediate context considering the unlimited number of audience that blogging may offer to us? The blogs provided the pre-service teachers in the study with a chance to share their feelings and thoughts with the rest of the world. Although the rapidly growing number of blogs all over the world makes it difficult to trace what people are blogging about, it is still encouraging to find that other person and discover and communicate with a small but dedicated group. 29 different people from all over the world including English teachers, teacher educators and students have left comments to the participants' blog posts and some continued blogging and interacting for a while. This played a role in enhancing the level and depth of the participants' reflectivity. As opposed to the afore-mentioned 
studies in the literature that noted little journal entries about self-awareness, the pre-service teachers frequently reflected upon their strengths and weaknesses as a teacher as well as their goals for the future. This interactive and friendly atmosphere encouraged them to share their very sincere feelings on their blogs.

Although the participants varied in the degree of their blog use, all of them approached the blogs positively, and stated in the post-study interviews that they liked being a part of it. They found blogs user-friendly since they had no difficulty in managing their blogs and enriching their blog content and templates through many additional widgets. Furthermore, almost all of the participants appreciated the fact that blogs provided them with the freedom to post what they would like to. This flexible environment allowed them to discuss several teaching and learning issues, and choose what to contribute to. Additionally, the asynchronous nature of communication through blogs was also welcome by most of the participants. Most of the participants agreed that teacher education programs could benefit greatly from integrating blogs as supplementary to classroom interaction.

\section{Conclusion}

The results suggest that blogs might offer possibilities to researchers and educationalists that traditional reflective tools mostly fall short of while retaining many of the more positive aspects. "Weblogs as reflective space offer the flexibility, personalization and informality to support preservice teacher informal reflection" (Shoffner, 2008, p. 132). Blogs as a flexible, professional reflective tool make it possible for pre-service teachers not only to interact with others, but also to actualize their unique voices in a non-threatening but encouraging atmosphere. This may spur selfinquiry, lifelong learning and professional development. Lortie (1975) referred to teaching as the egg carton profession since the walls of the classroom establish boundaries that separate teachers from each other. The collaborative, friendly and non-threatening atmosphere of blogging opens up a new channel for pre-service teachers through which they can go beyond the confines of their classrooms and stop engaging in teacher development in such isolation.

It is apparent that the rapidly evolving social software technologies have begun to question and change the ways we learn, use and teach languages. Researchers might explore how blogging might affect pre-service teachers' reflectivity if it is introduced at earlier stages of their teacher education. The impact of blog integration on instructional practices could be further investigated. Such inquiry will need to focus on the decision-making processes of the novel teachers, who have experienced blogging in their teacher education. Future research related to the instructional benefits of blogging should extend into different and varying learning communities.

\section{References}

Bartlett-Bragg, A. (2003). Blogging to learn. the knowledge tree: an e-journal of flexible learning in vet, edition 4. Retrieved on May 20, 2008 from http://knowledgetree.flexiblelearning.net.au/edition04/pdf/Blogging_to_Learn.pdf

Bean, T. W., \& Stevens, L. P. (2002). Scaffolding reflection for preservice and inservice teachers. Reflective Practice, 3(2), 205-218. 
Brescia, W. F. \& Miller, M. T. (2006). What's it worth? The perceived benefits of instructional blogging. Electronic Journal for the Integration of Technology in Education, 5, 44-52.

Farrell, T. S. C. (1999). Reflective practice in an EFL teacher development group.System 27,157172.

Galvez-Martin, M. E., Bowman, C. L., \& Morrison, M. A. (1998). An exploratory study of the level of reflection attained by preservice teachers. Mid-Western Educational Researcher, 11 (2), 918.

Gelter, H. (2003). Why is reflective thinking uncommon. Reflective Practice 4(3), 337-344.

Hatton, N., \& Smith, D. (1994). Facilitating reflection: Issues and research. Paper presented at the conference of Australian Teacher Education Association ( $24^{\text {th }}$ Brisbane, Queensland, Australia, July 3-6, 1994) 23pp.

Herring, S. C., Scheidt, L. A., Wright, E., \& Bonus, S. (2005).Weblogs as a bridging genre. Information Technology \& People, 18(2), $142-171$.

Ho, B., \& Richards, J. C. (1993). Reflective thinking through teacher journal writing: myths and realities. Perspectives, 5(2), 25-40. Retrieved, on November 1, 2008, from: http://sunzi1.lib.hku.hk/hkjo/view/10/1000060.pdf

Kajder, S., \& Bull, G. (2003). Scaffolding for struggling students: Reading and writing with blogs. Learning \& Leading with Technology, 31 (2), 32 - 35.

Kennedy, K. (2003). Writing with web logs. Retrieved on September 3, 2008, from: http://www.techlearning.com/db_area/archives/TL/2003/02/blogs.php

Lee, I. (2007). Preparing pre-service English teachers for reflective practice. ELT Journal, 61 (4), 321-329.

Liou, H. C. (2001). Reflective practice in a pre-service teacher education program for high school English teachers in Taiwan, ROC, System, 29, $197-208$.

Lortie, D. (1975). Schoolteacher: A sociological study. Chicago: University of Chicago Press.

Martindale, T. \& Wiley, D. A. (2005). Using weblogs in scholarship and teaching. TechTrends, 49 (2), $55-61$

McLaughlin, D., \& Hanifin, P. (1994). Empowering the novice: promoting reflection in preservice teacher education. Paper presented at the Annual Conference of the Australian Teacher Education Association (24 ${ }^{\text {th }}$, Brisbane, Queensland, Australia, July 3-6, 1994).

Mewborn, D. S. (1999). Reflective thinking among preservice elementary mathematics teachers. Journal for Research in Mathematics Education, 30 (3), 316 - 341.

Myers, B., Hudson, S. E., \& Pausch, R. (2000). Past, present, and future of user interface tools. ACM Transactions on Computer-Human Interaction, 7 (1), 3-28. 
Oravec, J. A. (2002). Bookmarking the world: Weblog applications in education. Journal of Adolescent \& Adult Literacy, 45 (7), 616 - 621.

Ray, B. B., \& Hocutt, M. M. (2006). Reflection and the middle school blogger: Do blogs support reflective practice? Meridian: A Middle School Computer Technologies Journal, 9(1). $\begin{array}{lllll}\text { Retrieved on } & \text { April 25, from: }\end{array}$ http://www.ncsu.edu/meridian/win2006/MS_blogs/index.htm

Shoffner, M. (2005). "If you write it down, you have to think about it": Incorporating weblogs into pre-service teachers' reflective practice. In C. Crawford et al. (Eds.), Proceedings of the Society for Instructional Technology and Education (pp. 2095-2100). Chesapeake, VA: AACE.

Shoffner, M. (2006). The potential of weblogs in pre-service teachers' reflective practice. In C. Crawford et al. (Eds.), Proceedings of Society for Information Technology and Teacher Education International Conference 2006 (pp. 2409-2415). Chesapeake, VA: AACE

Shoffner, M. (2008). What's technology got to do with it?: exploring reflection and technology in an English education methods course. In K. McFerrin et al. (Eds.), Proceedings of Society for Information Technology and Teacher Education International Conference 2008 (pp. 3596 3601). Chesapeake, VA: AACE

Stiler, G.M. \& Phileo, T. (2003) Blogging and blogspots: An alternative format for encouraging reflective practices among pre-service teachers, Education, 123 (4), 789-797.

Suzuki, R. (2004). Diaries as introspective research tools: From Ashton-Warner to blogs. Teaching English as a second or foreign language, 8( 1). Retrieved from http://wwwwriting.berkeley.edu/tesl-ej/ej29/int.html

Taggart, G. L., \& Wilson, A. P. (2005) Promoting reflective thinking in teachers: 50 action strategies. Thousand Oaks, CA: Corwin Press.

Wang, S.-K., \& Hsua, H.-Y. (2008). Reflections on using blogs to expand in-class discussion. TechTrends, 52(3), 81-85.

Wassell, B., \& Crouch, C. (2008). Fostering connections between multicultural education and technology: Incorporating weblogs into preservice teacher education. Journal of Technology and Teacher Education, 16 (2), 211-232.

West, R. E., Wright, G. A., \& Graham, C. R. (2005). Blogs, wikis, and aggregators: A new vocabulary for promoting reflection and collaboration in a preservice technology integration course. In C. Crawford et al. (Eds.), Proceedings of the Society for Instructional Technology and Education . (pp. 1653-1658). Chesapeake, VA : AACE.

White, N. (2006). Blogs and community: launching a new paradigm for online community? The Knowledge Tree, Edition 11. Retrieved from http://kt.flexiblelearning.net.au/wpcontent/uploads/2006/12/white.pdf

Williams, J. B., \& Jacobs, J. (2004). Exploring the use of blogs as learning spaces in the higher education sector. Australasian Journal of Educational Technology, 20(2), 232 - 247. 
Yang, S-H. (2005). EFL teacher learners' collaborative reflection through web-blogging. US-China Education Review, 2(9), $14 \quad-\quad 17 . \quad$ Retrieved from: http://www.teacher.org.cn/doc/ucedu200509/ucedu20050903.pdf

Yurkiw, S. (2006). Reflective journaling for the $21^{\text {st }}$ century (or the blog that helped devour fear of failure in the classroom). Joint Newsletter of the TTED and ESOL SIGs, Issue 2, 1-5. Retrieved from http://associates.iatefl.org/pages/materials/pd27.pdf

\section{Geniş Özet}

Web 2.0 araçlarının gelişimi ile birlikte, öğretmen adaylarının yansıtıcı düşüncelerini geliştirmek için öğretmen yetiştiren eğitimciler için yeni olanaklar ortaya çıkmıştır. Bu bağlamda, bu çalışma blog kullanımının öğretmen adaylarının yansıtıcı düşünmelerini geliştirmede ne şekilde etkili olduğunu araştırmayı amaçlamaktadır. Weblogların, öğretmen adaylarının fikirlerini ve duygularını yansıtabilecekleri bir ortam sağlayabileceğine, ve bu tehdit edici olmayan ancak yine de zorlayıcı ortamda başkaları ile işbirliği içinde bilgi üreteceklerine inanılmaktadır. Araştırma yansıtıcı düşüncenin gelişim sürecine odaklanmaktadır. Bu süreç dahilinde, bu çalışma öğretmen adaylarının blog yazılarında ele aldıkları konuları inceleyerek yansıtıcı düşünce gelişimlerini analiz eder.

\section{Yöntem}

$\mathrm{Bu}$ çalışma nitel araştırma paradigması çerçevesinde gerçekleştirilen bir durum çalışmasıdır. Çalışma örneklemi Orta Doğu Teknik Üniversitesi Yabancı Diller Eğitimi Bölümünde lisans eğitimi alan 12 öğretmen adayıdır. Çalışma 12 haftalık bir dönemi kapsamaktadır. Öğretmen adaylarının yansıtıcı blog yazıları ve yorumlardan oluşan arşivsel kayıtları, çalışma-öncesi ve sonrası yapılan görüşmeler ve araştırmacı tarafından çalışma süresince tutulan gözlem notları bu çalışmanın veri toplama yöntemlerini oluşturmaktadır. Araştırmada: (1) öğretmen adaylarının blog yazılarında ne tür konulara değindiği; (2) yansıtıcı düşüncenin seviyesinin betimsel ya da eleştirisel olup olmadığı; (3) blog yazı ve yorumlarının yansıtıcı düşüncesi seviyesi açısından ne tür farklılıklar gösterdiği; ve (4) bloglar aracılığıyla yansıtıcı düşüncenin zamanla nasıl değiştiği incelenmektedir. Araştırma boyunca elde edilen tüm blog içeriği kaydedilmiştir. Veriler öğretmen adaylarının blog yazılarnda yazdıkları konulara göre kodlanmıştır, ve bu konular eleştirel yansıtıcı düşünceyi tespit etmek için kullanılmıştır. İlk ve daha sonraki blog yazıları öğretmen adaylarının yansıtıcı düşüncelerindeki değişimi tespit etmek için karşılaştırılmıştır.

\section{Bulgular}

Araştırmanın sonuçları öğretmen adaylarının blog yazılarında çoğunlukla kendi kişisel eğitim kuramları, uygulama dersine dayanarak tespit ettikleri sorunlar, ve kişisel farkındalıklarıyla ilgili konular hakkında yazdıklarını göstermiştir. Blog yazılarında sordukları sorular incelendiğinde çoğunlukla yardım ve öneri istedikleri zaman soru sordukları görülmüştür. Blog yazılarındaki yansıtıcı düşünce seviyesi incelendiğinde, belirlenen kategorilerde yansıtıcı düşünce açısından bireysel faklılıklar olmasına rağmen araştırmaya katılan öğretmen adaylarının tamamının blog yazılarında bir ölçüye kadar yansıtıcı olduğu gözlemlenmiştir. Analize konu olan kategoriler ele alındığında, eleştirel düşünce seviyeleri için aşağıdaki sonuçlara ulaşılmıştır: 
- Öğretim Kuramları. Katılımcıların, kuramların derslerinde nasıl uygulandığından ziyade kişisel kuramları/görüşleri üzerinde eleştirel bir şekilde düşündüğü bulunmuştur.

- Yaklaşım ve Yöntemler. Bu kategorideki düşüncelerin eleştirel özellikleri, okul bağlamının değerlendirilmesine ve öğrencilerin öğretim sürecinin tasarımını ve uygulanmasını etkileyebilecek özelliklerine odaklanmıştır. Katılımcılar ayrıca, öğretmenlerin hem ders etkinliği hem de sınıf yönetiminin gerektirdiği bilgi ve deneyim hakkında da düşünmüşlerdir.

- Öğretimi Değerlendirme. Öğretmen adayları gözlemledikleri dersleri ve kendi mikroöğretim deneyimlerini değerlendirirken daha eleştirel bir yaklaşım sergilemektedir. Katılımcıların çoğu, mikro-öğretimden önceki ve sonraki görüşlerini paylaştılar. Bazıları ders planını tasarlarken öneri ve tavsiyeler istemişti; bazıları, derslerini gözlemleyen sorumlu öğretmenlerinden ve sınıf arkadaşlarından aldıkları geri bildirimlerle ilgili blog yazıları yazmıştı veya diğer bir kısmı ise, başkalarının derslerini analiz ederken iyi tasarlanmış bir ders planı nasıl olmalı sorusuna yönelik yönelik tavsiyelerde bulunmuştu.

- $\quad \ddot{z}$ farkındalık. Bu kategorideki yansımaların kritik özellikleri çoğunlukla kişisel hedeflerin belirlenmesi etrafında toplanmıştır. Çalışmadaki her katılımcının, gelecekte geliştirilmek için ihtiyaç duyduğu öğretim yönlerine dair yansıtıcı olarak düşündüğü saptanmıştır.

- Ö̆̆retime dair sorular. Katılımcılar çoğunlukla tavsiye ya da yardım istemek için soru sormuşlardır. Blogların katılımcılara daha çok kendini ifade için bir ortam sağladığını söylemek mümkündür.

Araştırma ayrıca blog yazıları ile yorumlar arasında yansıtıcı düşünce seviyesi açısından bir farklılık olup olmadığını da incelemiştir. Katılımcılar başkalarıyla karşılıklı iletişimde bulunduğu yorumlarda daha eleştirel ve yansitıcı olarak görülürken, hem yazılarda hem de yorumlarda daha çok kendi öğretim anlayışları ve kuramları hakkında görüş bildirmişlerdir. 12 hafta süren bu çalışma boyunca blog deneyiminin yansıtıcı düşünce seviyesi üzerinde nasıl bir etkisi olduğunu analiz etmek için de, katılımcıların önceki blog yazıları ile son dönemdeki blog yazıları analizde kullanılan kategoriler açısından karşılaştırılmıştır. Bu bulgulara göre, hemen hemen tüm katılımcıların kendi öğretim kuramları konusunda görüş bildirmeye başladıkları görülmüştür. Dahası, zamanla daha çok sorunları tartışır ve kendi çözümlerini önerir bir hale gelmişlerdir. Ancak daha eleştirel ve yansıtıcı sorular gözlemlenmemiştir.

\section{Tartışma ve Öneriler}

$\mathrm{Bu}$ çalışma, yaygın olarak kullanılan geleneksel yansıtıcı yöntemlere yönelik memnuniyetsizlik karışısında oluşan daha yantısıcı araç isteğine bir cevap olabilir. Bulgular, blogların geleneksel yansıtıcı araçların pek çok iyi yönünü korurken, onların veremediği yeni imkanları da araştırmacılar ve eğitimciler için sağlayabileceğini göstermektedir. Öğretmen adayları, blog deneyimine karşı olumlu yaklaşmışlardır. Elektronik erişilebilirlik, kayıtların arşivlenmesi, okuyucuların Web üzerinden dış kaynaklara bağlanması, sahiplik duygusu ve düşüncelerini paylaşabilecekleri kişisel bir alan sağlama firsatı da dahil olmak üzere blog özelliklerinin birçoğunu takdir ettiler. Ayrıca, pekçok katılımcı blog yazmanın yazma becerilerini geliştirdiğini söyledi. Mesajlarını yabancı bir dilde aktarmada daha rahat hissettiler ve birçoğu gelecekteki öğretiminde blogları kullanma konusundaki isteklerini dile getirdiler. Çoğunlukla bu olumlu sonuçlardan dolayı, öğretmen eğitim 
programlarının, blogları sınıf öğretimi ve etkileşime tamamlayıcı olarak entegre etmekten büyük ölçüde faydalanabileceği görüşünde birleştiler.

Ancak katılımcıların aktif bir şekilde blog kullanımlarını sağlayacak ve onları bu konuda teşvik edecek planlanmış aktivitelere ve rehberliğe ihtiyaç duydukları da görülmüştür. Bu nedenle, bloglar müfredata alınırken, böylesi bir kullanımın doğru planlanmasına gereken önem verilmelidir. Hızla gelişen sosyal yazılım teknolojilerinin, dil öğrenme, kullanma ve öğretme yöntemlerimizi sorgulamaya ve değiştirmeye başladığı ortadadır. Araştırmacılar, blogların öğretmen adaylarının öğretmenlik eğitiminin daha erken aşamalarında sunulması durumunda öğretmenlerin yansıtıcılığını nasıl etkileyebileceğini araştırabilir. Blog kullanımının öğretim uygulamaları üzerindeki etkisi daha fazla araştırılabilir. Blog yazmanın öğretim faydalarıyla ilgili olarak farklı öğrenim toplulukları ve ortamları da incelenebilir. 